\title{
The GH-releasing effect of acylated ghrelin in normal subjects is refractory to GH acute auto-feedback but is inhibited after short-term GH administration inducing IGF1 increase
}

\author{
A Benso*, E Gramaglia*, I Olivetti, M Tomelini, V Ramella Gigliardi, S Frara, E Calvi, S Belcastro, D H St Pierre, \\ E Ghigo and F Broglio \\ Division of Endocrinology, Diabetology and Metabolism, Department of Internal Medicine, San Giovanni Battista, Molinette Hospital, University of Turin, \\ Corso Dogliotti 14, 10126 Turin, Italy \\ (Correspondence should be addressed to F Broglio; Email: fabio.broglio@unito.it) \\ *(A Benso and E Gramaglia contributed equally to this work)
}

\begin{abstract}
Objective: GH secretion is regulated by an interplay between GH-releasing hormone (GHRH), somatostatin (SST), and other central and peripheral signals. Acylated ghrelin (AG) amplifies GH pulsatility acting, at least partially, independently from GHRH and SST. The GH response to GHRH is inhibited by recombinant human GH (rhGH), likely due to a SST-mediated negative GH auto-feedback. The effect of exogenous rhGH on the GH-releasing effect of AG has never been tested.

Design and methods: In six healthy volunteers, we studied the GH response to acute AG administration $(1.0 \mu \mathrm{g} / \mathrm{kg}$ i.v. $)$ during saline or rhGH infusion $(4.0 \mu \mathrm{g} / \mathrm{kg}$ per h i.v.) or after 4-day rhGH $(10.0 \mu \mathrm{g} / \mathrm{kg}$ s.c.) administration.

Results: Compared with saline, rhGH infusion increased GH levels $(P<0.01)$. During saline, acute i.v. AG induced a marked increase $(P<0.01)$ in GH levels similar to those observed after AG administration during rhGH infusion. During s.c. rhGH, IGF1 levels rose from day 0 to day 5 $(P<0.01)$. After 4-day s.c. rhGH, i.v. AG increased $(P<0.01)$ GH levels, though significantly $(P<0.05)$ less than on day 0.

Conclusions: The marked somatotroph-releasing effect of AG is refractory to a direct GH auto-feedback whereas is markedly inhibited after 4-day rhGH administration, suggesting the possibility of a selective IGF1-mediated inhibitory feedback.
\end{abstract}

European Journal of Endocrinology 168 509-514

\section{Introduction}

The neural control of GH secretion mainly depends on the tight interplay between GH-releasing hormone (GHRH) and somatostatin (SST) $(1,2,3,4,5,6)$. In addition, several neurotransmitters, neuropeptides, metabolic fuels, and also peripheral hormones, in particular insulin-like growth factor 1 (IGF1), have an important influence on somatotropic function mainly acting via the modulation of GHRH and SST release $(7,8)$.

In particular, the negative feedback exerted by IGF 1 on GH secretion involves direct effects at the pituitary level through activation of IGF1 receptors, leading to the inhibition of GH synthesis and release (9). Indirect CNS-mediated mechanisms have also been demonstrated. In fact, in animals, IGF1 has been shown to be able to stimulate SST and inhibit GHRH release acting at the hypothalamic level (9).

GH itself, directly and indirectly, modulates its own secretion, and this negative GH auto-feedback control involves many of the above-mentioned factors $(1,2,3$, $4,5,6,7,8)$. GH increases IGF1 and free fatty acid levels, which in turn inhibits GH secretion acting both at the pituitary and hypothalamic level $(10,11)$. However, the influence of IGF1 and free fatty acids does not account for the inhibitory effect shown by the acute administration of $\mathrm{GH}$ on the $\mathrm{GH}$ response to GHRH both in animals and in man that is instead mediated by SST (12). SST antiserum in rat and substances inhibiting hypothalamic SST release in man are able to completely restore the GH response to GHRH when inhibited by a previous recombinant human GH (rhGH) bolus $(12,13,14,15,16,17)$.

In recent years, the complexity of the regulation of the GH/IGF1 axis has been further enriched by the discovery of ghrelin, a peptidic hormone mainly deriving from gastric production that, in its acylated form, displays a potent GH-releasing activity via the activation of a specific receptor, the GH secretagogues (GHS) receptor type 1a (GHSR1a) $(18,19,20,21)$. 
Although many years have passed since its isolation, the actual role of acylated ghrelin (AG) in the physiological control of $\mathrm{GH}$ secretion is still a matter of debate and is likely to act as an amplifier of $\mathrm{GH}$ pulsatility rather than a true $\mathrm{GH}$ pulse generator as an alternative GHRH $(22,23)$. Although the physiological role of AG in the control of the somatotropic axis is probably less relevant than originally expected, anyway it remains that the exogenous administration of $A G$ as well as its synthetic analogues such as hexarelin or GHRP6 represents one of the most potent pharmacological stimuli of $\mathrm{GH}$ secretion in humans in vivo $(20,24,25)$.

Notably, despite this evidence, no information is available in the literature on the influence of $\mathrm{GH}$ and IGF1 levels themselves on the somatotroph responsiveness to AG in physiological conditions.

Based on the foregoing, the aim of this study was to verify whether the GH-releasing effect of $A G$ is influenced by the acute increase in GH levels induced by short-term infusion of rhGH and/or by the increase in IGF1 levels induced by 4-day s.c. rhGH administration in adult healthy volunteers. In order to test the specificity of GH or IGF1 feedback on the GH-releasing effect of AG, the effects on the prolactin (PRL) and cortisol responses to the gastric hormone were also evaluated.

\section{Materials and methods}

Six healthy young male volunteers (age (mean \pm s.E.M.), $27.8 \pm 3.1$ years; BMI, $23.1 \pm 2.3 \mathrm{~kg} / \mathrm{m}^{2}$ ) were studied. All the subjects gave their written informed consent to participate in the study, which had been approved by the Ethics Committee of the University of Turin.

All the subjects underwent the following three testing sessions in random order at least 30 days apart: i) acute AG administration $\left(1.0 \mu \mathrm{g} / \mathrm{kg}\right.$ i.v. as a bolus at $\left.0^{\prime}\right)$ during saline infusion from $-180^{\prime}$ to $+60^{\prime}$; ii) acute AG administration $\left(1.0 \mu \mathrm{g} / \mathrm{kg}\right.$ i.v. as a bolus at $\left.0^{\prime}\right)$ during $\mathrm{rhGH}\left(4.0 \mu \mathrm{g} / \mathrm{kg}\right.$ per h) i.v. infusion from $-180^{\prime}$ to $+60^{\prime}$; and iii) acute AG administration $(1.0 \mu \mathrm{g} / \mathrm{kg}$ i.v. as a bolus at $0^{\prime}$ ) during saline infusion from $-180^{\prime}$ to $+60^{\prime}$ after 4-day rhGH $(10.0 \mu \mathrm{g} / \mathrm{kg})$ s.c. administration at $2100 \mathrm{~h}$.

After overnight fasting, the tests began in the morning at 0830-0900 $\mathrm{h}, 30^{\prime}$ after an indwelling catheter had been placed into an antecubital vein of the forearm kept patent by slow infusion of isotonic saline.

Blood samples were taken every 15 min from time $-180^{\prime}$ up to $+60^{\prime}$. GH, PRL, and cortisol levels were assayed at each time point in all the sessions. IGF1 levels were assayed at $-180^{\prime}$ and at $+60^{\prime}$ in each session. IGF1, IGFBP3, GH, free fatty acids, insulin, and glucose were assayed at time $0^{\prime}$ in each session and at $0800 \mathrm{~h}$ on the following day after every evening rhGH s.c. administration.
GH levels $(\mu \mathrm{g} / \mathrm{l})$ were measured in duplicate by immunoradiometric assay (IRMA; hGH-CT, RADIM, Pomezia, Italy): sensitivity, $0.04 \mu \mathrm{g} / \mathrm{l}$; inter- and intraassay coefficient of variation $(\mathrm{CV})$ range, 4.6 and $3.7 \%$ respectively. IGF1 levels $(\mathrm{ng} / \mathrm{ml})$ were measured in duplicate by IRMA (IGF1 SM-C-RIA-CT, PANTEC, Torino, Italy): sensitivity, $0.25 \mathrm{ng} / \mathrm{ml}$; inter- and intraassay CV range, 10.8 and $9.5 \%$ respectively. IGFBP 3 levels $(\mu \mathrm{g} / \mathrm{ml})$ were measured in duplicate by IRMA (IGFBP3 IRMA, IMMUNOTECH SA, Marseille, France): sensitivity, $0.050 \mu \mathrm{g} / \mathrm{ml}$; inter- and intra-assay $\mathrm{CV}$ range, 9.5 and $6.0 \%$ respectively.

Cortisol levels $(\mu \mathrm{g} / \mathrm{dl})$ were measured in duplicate by IRMA (RADIM): sensitivity, $0.09 \mu \mathrm{g} / \mathrm{dl}$; inter- and intraassay CV range, 7.2 and $8.0 \%$ respectively. PRL levels $(\mathrm{ng} / \mathrm{ml})$ were measured in duplicate by IRMA (PANTEC): sensitivity, $0.5 \mathrm{ng} / \mathrm{ml}$; inter- and intraassay CV range, 8.0 and $2.8 \%$ respectively. Plasma glucose levels $(\mathrm{mg} / \mathrm{dl} ; 1 \mathrm{mg} / \mathrm{dl}=0.05551 \mathrm{mmol} / \mathrm{l})$ were measured by the glucose oxidase colorimetric method (GLUCOFIX; Menarini Diagnostics, Florence, Italy).

Serum insulin levels $(\mu \mathrm{U} / \mathrm{ml})$ were measured in duplicate by IRMA (INSIK-5; SORIN Biomedica, Saluggia, Italy). The sensitivity of the insulin assay was $2.5 \pm 0.3 \mu \mathrm{U} / \mathrm{ml}$. The inter- and intra-assay $\mathrm{CV}$ values were $6.2-10.8$ and $5.5-10.6 \%$ respectively.

Serum free fatty acid (FFA) levels (mEq/l) were measured by enzymatic colorimetric method (Wako Chemicals GmbH, Neuss, Germany). The inter- and intra-assay CV values were 1.1 and $4.1 \%$ respectively. All the samples from an individual subject were analyzed in a single run of each assay. All samples from an individual subject were analyzed together.

The hormonal responses are expressed as absolute mean levels or areas under the curves (AUCs) calculated by trapezoidal integration. The statistical analysis was carried out using nonparametric ANOVA (MannWhitney $U$ test), as appropriate. The results are expressed as mean \pm s.E.M.

\section{Results}

Mean ( \pm s.E.M.) GH levels during saline infusion were $0.6 \pm 0.1 \mu \mathrm{g} / \mathrm{l}$ corresponding to an $\mathrm{AUC}_{\text {saline }}^{t-180^{\prime}-t 0^{\prime}}$ of $111.0 \pm 56.0 \mu \mathrm{g} / \mathrm{l} \times \min$. During rhGH infusion starting at $-180^{\prime}$, GH levels progressively rose up to a steadystate level at time $-135^{\prime}$; in particular, mean GH levels ${ }^{t-135^{\prime}-t 0^{\prime}}$ were $29.8 \pm 2.6 \mu \mathrm{g} / \mathrm{l}$ corresponding to an $\mathrm{AUC}_{\text {rhGH }}^{t-135^{\prime}-t 0^{\prime}}$ of $3336.0 \pm 171.0 \mu \mathrm{g} / \mathrm{l} \times$ min, which as expected, was significantly higher $(P<0.01)$ than that observed during saline at the corresponding time points $\left(\mathrm{AUC}_{\text {saline }}^{t-135^{\prime}-t 0^{\prime}}: 93.0 \pm 60.0 \mu \mathrm{g} / \mathrm{l} \times\right.$ min; Fig. 1).

During saline infusion, the acute i.v. AG administration induced a marked increase $(P<0.01)$ in $\mathrm{GH}$ levels $\left(\Delta\right.$ peak $_{\text {saline }+ \text { AG }}^{t O^{\prime}-t 60^{\prime}}, 53.0 \pm 5.8 \mu \mathrm{g} / \mathrm{l} ; \Delta \mathrm{AUC}_{\text {saline }}^{t \mathrm{O}^{\prime}-t 6 \mathrm{AG}^{\prime}}$, $2054.0 \pm 161.0 \mu \mathrm{g} / \mathrm{l} \times \mathrm{min})$ that were not different from that observed after acute i.v. AG administration 


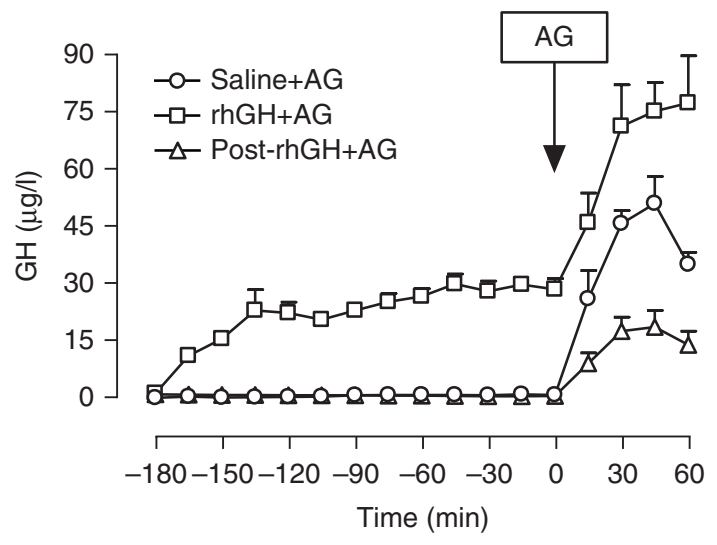

Figure 1 Mean \pm SEM GH responses to acute $A G$ administration $(1.0 \mu \mathrm{g} / \mathrm{kg}$ i.v. $)$ during saline or rhGH infusion $(4.0 \mu \mathrm{g} / \mathrm{kg} / \mathrm{h}$ i.v. $)$ or after 4-day rhGH (10.0 $\mu \mathrm{g} / \mathrm{kg}$ s.c.) administration. AG, acylated ghrelin; rhGH, recombinant human $\mathrm{GH}$.

during rhGH infusion ( $\Delta$ peak $_{\mathrm{rhGH}+\mathrm{AG}}^{t \mathrm{O}^{\prime}-t 6 \mathrm{O}^{\prime}}, \quad 55.6 \pm$ $10.0 \mu \mathrm{g} / \mathrm{l} ; \Delta \mathrm{AUC}_{\mathrm{rhGH}+\mathrm{AG}}^{t \mathrm{O}^{\prime}-t 60^{\prime}}, 1962.0 \pm 319.0$; Fig. 2). IGF1, IGFBP3, glucose, and insulin levels both at time $0^{\prime}$ and at time $60^{\prime}$ were similar in both sessions (data not shown).

During treatment with $10.0 \mu \mathrm{g} / \mathrm{kg}$ per day $\mathrm{rhGH}$, IGF1 levels progressively rose from day 0 levels $(212.2 \pm 15.6 \mu \mathrm{g} / \mathrm{l})$ reaching statistical significance on day $3(287.5 \pm 26.6 \mu \mathrm{g} / \mathrm{l} ; P<0.01$ vs baseline $)$ and then showed a further increase on day 4 (306.2 \pm $36.9 \mu \mathrm{g} / \mathrm{l} ; \mathrm{P}<0.01$ vs baseline) (Fig. 3). As expected, a concomitant increase $(P<0.05)$ in $\mathrm{GH}$ levels was also observed (day 0, $0.2 \pm 0.1 \mu \mathrm{g} / \mathrm{l}$; day 3, $1.2 \pm 0.7 \mu \mathrm{g} / \mathrm{l}$; day $4,1.4 \pm 0.9 \mu \mathrm{g} / \mathrm{l}$; Fig. 3$)$. On the contrary, no significant variations in IGFBP3, insulin, free fatty acids, and glucose levels were observed after 4-day rhGH s.c. treatment (data not shown).

After 4-day s.c. rhGH treatment, the i.v. administration of AG induced a significant increase $(P<0.01)$ in GH levels $\left(\Delta\right.$ peak $_{\text {post-rhGH }+ \text { AG }}^{t 0^{\prime}-t 60^{\prime}}, 19.0 \pm 4.1 \mu \mathrm{g} / \mathrm{l} ; \Delta \mathrm{AUC}$ post-rhGH $\left.+\mathrm{AG}^{t \mathrm{O}^{\prime}-t 60^{\prime}}, 753.0 \pm 174.0 \mu \mathrm{g} / \mathrm{l} \times \mathrm{min}\right)$ that was, however, significantly $(P<0.05)$ lower than that observed on day 0 (Fig. 2).

As expected, the administration of AG on day 0 also induced significant increases in PRL and cortisol levels $(P<0.05)$ that were similar to those observed after $A G$ during rhGH i.v. administration or after 4-day rhGH s.c. administration (Table 1). In all the sessions, baseline PRL and cortisol levels were similar (data not shown). Ghrelin administration induced a transient facial flushing in two subjects. No side effects during rhGH i.v. or s.c. administration were observed.

\section{Discussion}

The results of this study show that the somatotrophreleasing effect of $A G$ is refractory to the direct inhibitory effect of a short-term elevation of GH levels without increase in IGF1 levels, while it is markedly inhibited in the presence of increased IGF1 levels induced by 4-day rhGH administration.

AG has been isolated as an endogenous ligand of the GHSR $1 \mathrm{a}$ and emerged as one of the most potent and reproducible gender-independent stimuli of $\mathrm{GH}$ secretion in vivo during the lifespan $(18,19,20,21)$.

The GH-releasing effect of AG is mediated by actions on the pituitary and, mainly, within the hypothalamus, in particular, through a positive action on GHRHsecreting neurons and a concomitant functional antagonism of SST activity (26).

Different from GHRH, the GH-releasing activity of AG has already been reported to be refractory to the most important inhibitory inputs on GH secretion such as glucose, free fatty acids and $\beta$-adrenergic stimulation, all acting to increase the hypothalamic SST release (26), and even to be resistant to the inhibitory effect of SST administration itself $(26,27)$.

Thus, our present observation that a short-term increase in circulating GH levels induced by rhGH i.v. infusion fails to inhibit the $\mathrm{GH}$ response to $\mathrm{AG}$ is not surprising. In fact, it is well accepted both in animals and in humans that the negative GH auto-feedback mechanism is mainly mediated by the release of hypothalamic SST $(28,29)$.

On the other hand, interestingly, our data clearly show that the GH response to AG is markedly inhibited after 4-day s.c. rhGH administration, able to induce a significant increase in IGF1 levels, though still in the normal range, without sensible variations in circulating $\mathrm{GH}$ levels. Although a definitive proof cannot be drawn by our experimental model, the negative correlation we observed between the changes in the $\mathrm{GH}$ responses to AG and in IGF1 levels before and after s.c. rhGH treatment (data not shown) might suggest a causative relationship between the two phenomena, i.e. the

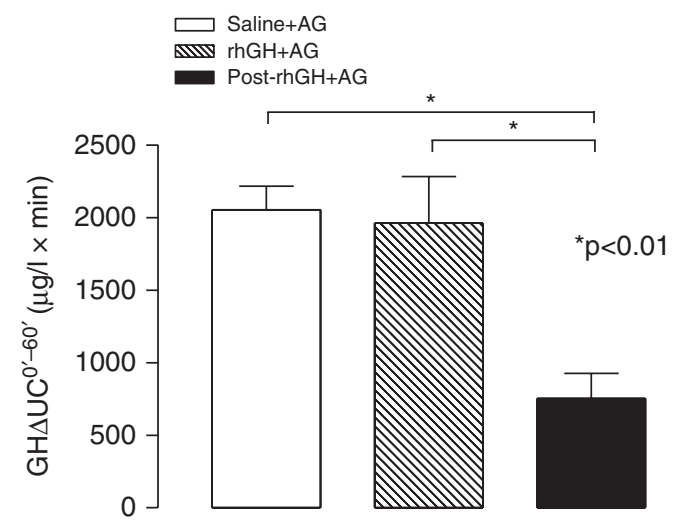

Figure 2 Mean \pm SEM $\triangle A \cup C 0^{\prime}-60^{\prime}$ GH responses to acute $A G$ administration $(1.0 \mu \mathrm{g} / \mathrm{kg}$ i.v.) during saline or rhGH infusion (4.0 $\mu \mathrm{g} / \mathrm{kg} / \mathrm{h}$ i.v.) or after 4-day rhGH (10.0 $\mu \mathrm{g} / \mathrm{kg}$ s.c.) administration. $\Delta$ AUC, $\Delta$ area under the curve; AG, acylated ghrelin; rhGH, recombinant human $\mathrm{GH}$. 

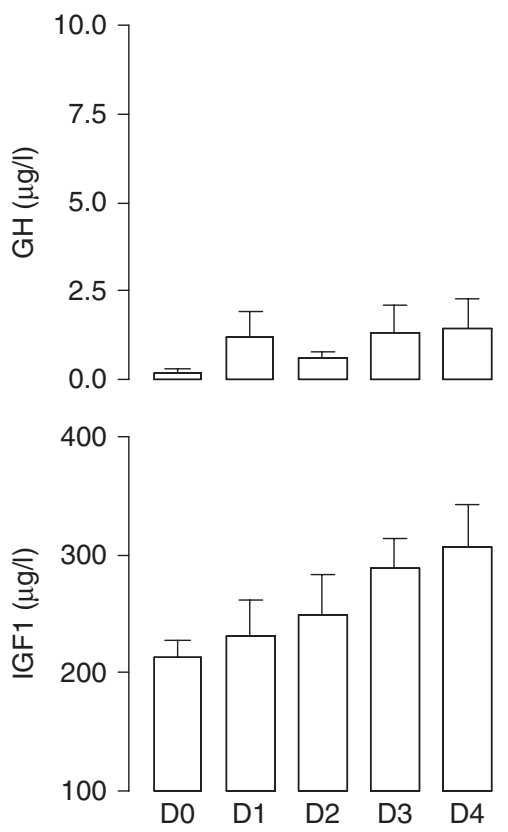

Figure 3 Mean \pm SEM GH and IGFI levels at baseline (D0) and during 4-day rhGH (10.0 $\mu \mathrm{g} / \mathrm{kg}$ s.c.) treatment (from D1 to D4). D0, day 0 ; D1, day 1; D2, day 2; D3, day 3; D4, day 4.

possibility of a selective inhibitory effect of IGF1 on the GH-releasing effect of AG.

Notably, a definitive demonstration of this hypothesis could derive from the evaluation of the effects of the direct administration of exogenous IGF1 on the GH response to AG, provided that IGF1 is administered at a dose not able to modify spontaneous GH secretion. Actually, in our study, the dose of $10 \mu \mathrm{g} / \mathrm{kg}$ rhGH was chosen as the one previously reported to be the minimal effective to increase IGF1 levels in both males and females (30). There is a wealth of in vitro and in vivo animal data showing that IGF1 inhibits GH release acting either at the pituitary or the hypothalamic level $(31,32)$ via inhibition of GHRH and/or stimulation of SST release $(29,31)$.

As the GH-releasing activity of AG is supposed to be mediated by functional antagonism of SST activity at both the pituitary and the hypothalamic level, it is

Table 1 Mean ( \pm S.E.M.) PRL and cortisol responses to acute AG administration $(1.0 \mu \mathrm{g} / \mathrm{kg}$ i.v.) during saline or $\mathrm{rhGH}$ infusion $(4.0 \mu \mathrm{g} / \mathrm{kg}$ per $\mathrm{h}$ i.v. $)$ or after 4 -day $\mathrm{rhGH}(10.0 \mu \mathrm{g} / \mathrm{kg}$ s.c.) administration.

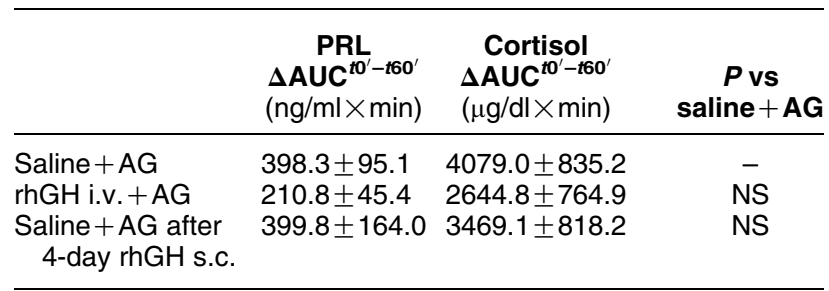

PRL, prolactin; $\triangle \mathrm{AUC}, \Delta$ area under the curve; AG, acylated ghrelin; rhGH, recombinant human GH; NS, not significant. unlikely that the inhibitory effect of rhIGF1 on the GH response to AG takes place via activation of somatostatinergic pathways (33). Thus, as there is evidence that IGF1 inhibits hypothalamic GHRH release, it is likely that the inhibitory effect of IGF1 on the GH response to AG might be mediated by counteracting its stimulatory effect on GHRH neuron activity (33). Alternatively, the possibility of a direct effect at the pituitary level cannot be excluded. In fact, prolonged exposure to $\mathrm{GH}$ has been reported to be able to decrease GHSR 1a mRNA levels both at the pituitary and the hypothalamic level in rats $(34,35,36)$ through IGF1independent mechanisms (36).

Unfortunately, our study model in vivo in humans does not allow to distinguish the pituitary from the hypothalamic effects, nor to fully define the distinct role of the 4-day GH exposure or of the increased IGF1 levels per se. However, the hypothesis of a mechanism involving the modulation of GHSR 1a level seems unlikely as both the responses of PRL and cortisol (due to the ACTH-releasing effect) to AG are not modified by either acute or prolonged rhGH administration. In fact, though elicited at different sites (e.g. lactotroph cells in the pituitary and CRH/AVP-secreting cells in the hypothalamus respectively), both actions have been clearly shown to be mediated by the activation of GHSR1a itself $(21,37)$.

Similarly, the hypothesis that the impairment of the GH response to AG after 4-day rhGH treatment could be mediated by other factors than the increase in IGF 1 levels has to be considered. In fact, prolonged $\mathrm{GH}$ treatment has been reported to increase glucose and free fatty acids levels (38). However, as reported before, the GH response to AG has been clearly shown to be refractory to the inhibitory effect of both glucose and free fatty acids (26), and moreover, in this study, no significant variation of glucose and free fatty acids levels were detected after rhGH treatment.

On the contrary, although circulating AG and unacylated ghrelin levels were not assayed, the theoretical possibility that the different GH responses could be related to inter-session differences in blood AG levels after i.v. administration is very unlikely as the test order was randomized and each subject received the same i.v. AG dose in each session. Similarly, the hypothesis that the impaired $\mathrm{GH}$ response to $\mathrm{AG}$ after 4-day s.c. GH administration is related to a random effect is very remote despite the lack of a control arm, taking into account the well known high intra-subject reproducibility of the somatotroph responsiveness to natural and synthetic GHS ((20) and F Broglio, unpublished results).

In conclusion, our results indicate that the somatotroph-releasing effect of AG is refractory to the direct inhibitory effect of a short-term elevation of GH levels while it is markedly inhibited in the presence of increased IGF1 levels induced by 4-day rhGH administration, opening the possibility, in agreement with 
previous studies with synthetic GHS (33), of a selective IGF1-mediated feedback.

\section{Declaration of interest}

The authors declare that there is no conflict of interest that could be perceived as prejudicing the impartiality of the research reported.

\section{Funding}

This research did not receive any specific grant from any funding agency in the public, commercial or not-for-profit sector.

\section{Acknowledgements}

The authors wish to thank Drs F Prodam and F Riganti for their support. The skillful technical assistance of Dr A Bertagna, M Taliano, and A Barberis is also acknowledged.

\section{References}

1 Bluet-Pajot MT, Epelbaum J, Gourdji D, Hammond C \& Kordon C. Hypothalamic and hypophyseal regulation of growth hormone secretion. Cellular and Molecular Neurobiology 199818 101-123. (doi:10.1023/A:1022579327647)

2 Arvat E, Gianotti L, Giordano R, Broglio F, Maccario M, Lanfranco F, Muccioli G, Papotti M, Graziani A, Ghigo E et al. Growth hormone-releasing hormone and growth hormone secretagogue-receptor ligands: focus on reproductive system. Endocrine 200114 35-43. (doi:10.1385/ENDO:14:1:035)

3 Veldhuis JD \& Bowers CY. Human GH pulsatility: an ensemble property regulated by age and gender. Journal of Endocrinological Investigation 200326 799-813.

4 Goldenberg N \& Barkan A. Factors regulating growth hormone secretion in humans. Endocrinology and Metabolism Clinics of North America 200736 37-55. (doi:10.1016/j.ecl.2006.11.003)

5 Gahete MD, Durán-Prado M, Luque RM, Martínez-Fuentes AJ, Quintero A, Gutiérrez-Pascual E, Córdoba-Chacón J, Malagón MM, Gracia-Navarro F \& Castaño JP. Understanding the multifactorial control of growth hormone release by somatotropes: lessons from comparative endocrinology. Annals of the New York Academy of Sciences 20091163 137-153. (doi:10.1111/j.1749-6632.2008. 03660.x)

6 López M, Nogueiras R, Tena-Sempere M \& Diéguez C. Orexins (hypocretins) actions on the GHRH/somatostatin-GH axis. Acta Physiologica 2010198 325-334. (doi:10.1111/j.1748-1716. 2009.02042.x)

7 Picha ME, Strom CN, Riley LG, Walker AA, Won ET, Johnstone WM \& Borski RJ. Plasma ghrelin and growth hormone regulation in response to metabolic state in hybrid striped bass: effects of feeding, ghrelin and insulin-like growth factor- 1 on in vivo and in vitro GH secretion. General and Comparative Endocrinology 2009161 365-372. (doi:10.1016/j.ygcen.2009.01.026)

8 Romero CJ, Ng Y, Luque RM, Kineman RD, Koch L, Bruning JC \& Radovick S. Targeted deletion of somatotroph insulin-like growth factor-1 signaling in a cell-specific knockout mouse model. Molecular Endocrinology 201024 1077-1089. (doi:10.1210/me. 2009-0393)

9 Eppler E, Jevdjovic T, Maake C \& Reinecke M. Insulin-like growth factor-1 (IGF1) and its receptor (IGF1R) in the rat anterior pituitary. European Journal of Neuroscience 200725 191-200. (doi:10.1111/j.1460-9568.2006.05248.x)

10 Nass R, Toogood AA, Hellmann P, Bissonette E, Gaylinn B, Clark R \& Thorner MO. Intracerebroventricular administration of the rat growth hormone $(\mathrm{GH})$ receptor antagonist G118R stimulates GH secretion: evidence for the existence of short loop negative feedback of GH. Journal of Neuroendocrinology $2000 \mathbf{1 2}$ 1194-1199. (doi:10.1046/j.1365-2826.2000.00586.x)

11 Peng XD, Park S, Gadelha MR, Coschigano KT, Kopchick JJ, Frohman LA \& Kineman RD. The growth hormone (GH)-axis of GH receptor/binding protein gene-disrupted and metallothioneinhuman GH-releasing hormone transgenic mice: hypothalamic neuropeptide and pituitary receptor expression in the absence and presence of GH feedback. Endocrinology 2001142 1117-1123. (doi:10.1210/en.142.3.1117)

12 Arvat E, Di Vito L, Gianotti L, Ramunni J, Boghen MF, Deghenghi R, Camanni F \& Ghigo E. Mechanisms underlying the negative growth hormone $(\mathrm{GH})$ autofeedback on the GH-releasing effect of hexarelin in man. Metabolism $1997 \mathbf{4 6}$ 83-88. (doi:10.1016/S0026-0495(97)90173-6)

13 Tannenbaum GS. Evidence for autoregulation of growth hormone secretion via the central nervous system. Endocrinology 1980107 2117-2120. (doi:10.1210/endo-107-6-2117)

14 Massara F, Ghigo E, Molinatti P, Mazza E, Locatelli V, Müller EE \& Camanni F. Potentiation of cholinergic tone by pyridostigmine bromide re-instates and potentiates the growth hormone responsiveness to intermittent administration of growth hormonereleasing factor in man. Acta Endocrinologica 1986113 12-16.

15 Ross RJ, Tsagarakis S, Grossman A, Nhagafoong L, Touzel RJ, Rees LH \& Besser GM. GH feedback occurs through modulation of hypothalamic somatostatin under cholinergic control: studies with pyridostigmine and GHRH. Clinical Endocrinology 198727 727-733. (doi:10.1111/j.1365-2265.1987.tb02957.x)

16 Arvat E, Ghigo E, Nicolosi M, Boffano GM, Bellone J, Yin-Zhang W, Mazza E \& Camanni F. Galanin reinstates the growth hormone response to repeated growth hormone-releasing hormone administration in man. Clinical Endocrinology 199236 347-350. (doi:10.1111/j.1365-2265.1992.tb01458.x)

17 Lanzi R \& Tannenbaum GS. Time-dependent reduction and potentiation of growth hormone $(\mathrm{GH})$ responsiveness to GH-releasing factor induced by exogenous $\mathrm{GH}$ : role for somatostatin. Endocrinology 1992130 1822-1828. (doi:10.1210/en.130.4. 1822)

18 Hosoda H, Kojima M \& Kangawa K. Ghrelin and the regulation of food intake and energy balance. Molecular Interventions 20022 494-503. (doi:10.1124/mi.2.8.494)

19 Kangawa K, Kojima M \& Hosoda H. Discovery of ghrelin and its physiological significance. Nihon Rinsho. Japanese Journal of Clinical Medicine 20049 (Suppl 62) 317-323.

20 Van der Lely AJ, Tschöp M, Heiman ML \& Ghigo E. Biological, physiological, pathophysiological, and pharmacological aspects of ghrelin. Endocrine Reviews 200425 426-457. (doi:10.1210/er. 2002-0029)

21 Ghigo E, Broglio F, Arvat E, Maccario M, Papotti M \& Muccioli G. Ghrelin: more than a natural GH secretagogue and/or an orexigenic factor. Clinical Endocrinology 200562 1-17. (doi:10.1111/j.1365-2265.2004.02160.x)

22 Farhy LS \& Veldhuis JD. Deterministic construct of amplifying actions of ghrelin on pulsatile growth hormone secretion. American Journal of Physiology. Regulatory, Integrative and Comparative Physiology 2005288 R1649-R1663. (doi:10.1152/ ajpregu.00451.2004)

23 Zizzari P, Halem H, Taylor J, Dong JZ, Datta R, Culler MD, Epelbaum J \& Bluet-Pajot MT. Endogenous ghrelin regulates episodic growth hormone $(\mathrm{GH})$ secretion by amplifying $\mathrm{GH}$ pulse amplitude: evidence from antagonism of the GH secretagogue-R 1a receptor. Endocrinology 2005146 3836-3842. (doi:10.1210/en. 2005-0212)

24 Matsuoka H, Hosoda H, Sugawara H, Iwama S, Kim HS, Kangawa K \& Sugihara S. Short-term secretory regulation of ghrelin during growth hormone provocative tests in prepubertal children with various growth hormone secretory capacities. Hormone Research 200564 274-279. (doi:10.1159/000089294)

25 Nass R, Gaylinn BD \& Thorner MO. The role of ghrelin in GH secretion and GH disorders. Molecular and Cellular Endocrinology 2011340 10-14. (doi:10.1016/j.mce.2011.03.021) 
26 Broglio F, Arvat E, Benso A, Gottero C, Prodam F, Granata R, Papotti M, Muccioli G, Deghenghi R \& Ghigo E. Ghrelin: much more than a natural growth hormone secretagogue. Israel Medical Association Journal 20024 607-613.

27 Arvat E, Broglio F, Aimaretti G, Benso A, Giordano R, Deghenghi R \& Ghigo E. Ghrelin and synthetic GH secretagogues. Best Practice \& Research. Clinical Endocrinology \& Metabolism 200216 505-517. (doi:10.1053/beem.2002.0213)

28 Ghigo E, Arvat E, Gianotti L, Lanfranco F, Broglio F, Aimaretti G, Maccario M \& Camanni F. Hypothalamic growth hormoneinsulin-like growth factor-I axis across the human life span. Journal of Pediatric Endocrinology \& Metabolism 200013 1493-1502.

29 Giustina A \& Veldhuis JD. Pathophysiology of the neuroregulation of growth hormone secretion in experimental animals and the human. Endocrine Reviews 199819 717-797. (doi:10.1210/er. 19.6.717)

30 Ghigo E, Aimaretti G, Maccario M, Fanciulli G, Arvat E, Minuto F, Giordano G, Delitala G \& Camanni F. Dose-response study of GH effects on circulating IGF1 and IGFBP3 levels in healthy young men and women. American Journal of Physiology $1999 \mathbf{2 7 6}$ E1009-E1013.

31 Melmed S, Yamashita S, Yamasaki H, Fagin J, Namba H, Yamamoto H, Weber M, Morita S, Webster J \& Prager D. IGF1 receptor signaling: lessons from the somatotroph. Recent Progress in Hormone Research 199651 189-215 (discussion 215-216).

32 Sheppard MS \& Bala RM. Insulin-like growth factor inhibition of growth hormone secretion. Canadian Journal of Physiology and Pharmacology 189664 525-530. (doi:10.1139/y86-087)

33 Ghigo E, Gianotti L, Arvat E, Ramunni J, Valetto MR, Broglio F, Rolla M, Cavagnini F \& Müller EE. Effects of recombinant human insulin-like growth factor-1 administration on growth hormone (GH) secretion, both spontaneous and stimulated by GH-releasing hormone or hexarelin, a peptidyl GH secretagogue, in humans. Journal of Clinical Endocrinology and Metabolism 1999 84 285-290. (doi:10.1210/jc.84.1.285)

34 Bennett PA, Thomas GB, Howard AD, Feighner SD, van der Ploeg LH, Smith RG \& Robinson IC. Hypothalamic growth hormone secretagogue-receptor (GHS-R) expression is regulated by growth hormone in the rat. Endocrinology $19971384552-4557$. (doi:10.1210/en.138.11.4552)

35 Nass R, Gilrain J, Anderson S, Gaylinn B, Dalkin A, Day R, Peruggia M \& Thorner MO. High plasma growth hormone (GH) levels inhibit expression of $\mathrm{GH}$ secretagogue receptor messenger ribonucleic acid levels in the rat pituitary. Endocrinology 2000141 2084-2089. (doi:10.1210/en.141.6.2084)

36 Kamegai J, Wakabayashi I, Miyamoto K, Unterman TG, Kineman RD \& Frohman LA. Growth hormone-dependent regulation of pituitary GH secretagogue receptor (GHS-R) mRNA levels in the spontaneous dwarf rat. Neuroendocrinology $1998 \mathbf{6 8}$ 312-318. (doi:10.1159/000054379)

37 Broglio F, Arvat E, Benso A, Papotti M, Muccioli G, Deghenghi R \& Ghigo E. Ghrelin: endocrine and non-endocrine actions. Journal of Pediatric Endocrinology \& Metabolism 20025 (Suppl 15) 1219-1227.

38 Krusenstjerna-Hafstrøm T, Clasen BF, Møller N, Jessen N, Pedersen SB, Christiansen JS \& Jørgensen JO. Growth hormone (GH)-induced insulin resistance is rapidly reversible: an experimental study in GH-deficient adults. Journal of Clinical Endocrinology and Metabolism 201196 2548-2557. (doi:10.1210/jc. 2011-0273)

Received 11 August 2012

Revised version received 19 December 2012

Accepted 07 January 2013 